\title{
KINERJA PERTUMBUHAN DAN FCR IKAN PATIN (Pangasius sp) DENGAN LAMA PEMUASAAN YANG BERBEDA
}

\author{
Ego Arta Armanda ${ }^{1}$, Andi Rahmad Rahim ${ }^{2}$, Muh Sulaiman Dadiono ${ }^{2}$ \\ 1. Mahasiswa Program Prodi Akuakultur, Fakultas Pertanian Universitas Muhammadiyah Gresik \\ 2. Dosen Program Studi Akuakultur, Fakultas Pertanian Universitas Universitas Muhammadiyah \\ Gresik \\ E-mail : artaarmanda1996@gmail.com; Phone : 082236660065
}

\begin{abstract}
Patin fish including commodity that has bright prospects for cultivated. The high cost of production due to the expensive price of feed and feed needs high push the development of feeding methods are efficient and effective. One of them is with the way the mastery feed. This research aims to test the effects of mastery and growth, survival and feed conversion ratio in fish catfish. Research using complete randomized design (CRD) with 4 treatment Treatment A (mastery 8 hours), Treatment B (mastery 12 hours), the treatment C (mastery 24 hours), the treatment of D (mastery 48 hours) and three replicates. The parameters analyzed are the absolute length growth, growth of absolute weight, daily growth rate, survival and FCR. Every farming fish seed stocked catfish the size of $9-10 \mathrm{~cm}$ with a tail of the density is $10 / \mathrm{m}$. Based on the results of the research that has been done, then it can be inferred that mastery on fish catfish show a real difference on the variable weighted absolute, absolute length, daily growth rate, and FCR. Treatment B (mastery 12 hours) provide the absolute weight, length, and the absolute best FCR. The best daily growth rate on treatment A (mastery 8 hours). While not survival variables showed a significant difference in all treatments.
\end{abstract}

Keywords: fish catfish, mastery, growth, survival, feed convertion ratio.

\section{ABSTRAK}

Ikan patin termasuk komoditi yang memiliki prospek cerah untuk dibudidayakan. Tingginya biaya produksi akibat mahalnya harga pakan dan kebutuhan pakan yang tinggi mendorong perkembangan metode pemberian pakan yang efisien dan dan efektif. Salah satunya adalah dengan cara pemuasaan pakan. Penelitian ini bertujuan untuk menguji efek dari pemuasaan dan pertumbuhan, kelangsungan hidup dan rasio konversi pakan pada ikan patin. Penelitian menggunakan rancangan acak lengkap (RAL) dengan 4 perlakuan Perlakuan A (pemuasaan 8 jam), Perlakuan B (pemuasaan 12 jam), Perlakuan C (pemuasaan 24 jam), Perlakuan D (pemuasaan 48 jam) dan 3 kali ulangan. Parameter yang dianalisis adalah pertumbuhan panjang mutlak, pertumbuhan bobot mutlak, laju pertumbuhan harian, kelangsungan hidup dan FCR. Setiap tempat budidaya ditebar benih ikan patin ukuran 9-10 cm dengan kepadatan 10 ekor/media. Berdasarkan hasil penelitian yang telah dilakukan, maka dapat disimpulkan bahwa pemuasaan pada ikan patin menunjukkan perbedaan nyata pada variabel bobot mutlak, panjang mutlak, laju pertumbuhan harian, dan FCR. Perlakuan B (pemuasaan 12 jam) memberikan bobot mutlak, panjang mutlak, dan FCR terbaik. Laju pertumbuhan harian terbaik pada perlakuan A (pemuasaan 8 jam). Sedangkan variabel kelangsungan hidup tidak memperlihatkan perbedaan nyata pada semua perlakuan.

Kata kunci: ikan patin, pemuasaan, pertumbuhan, sintasan, rasio konversi pakan. 


\section{PENDAHULUAN}

Ikan patin merupakan salah satu jenis ikan air tawar asli Indonesia yang tersebar di sebagian wilayah Sumatera dan Kalimantan (Djarijah, 2001). Ikan patin termasuk komoditi yang memiliki prospek cerah untuk dibudidayakan. Hal tersebut dikarenakan ikan patin mempunyai kelebihan yaitu rasa dagingnya yang lezat dan gurih, ukuran per individunya besar, pertumbuhannya yang pesat, dan mudah dibudidayakan (Susanto dan Khairul, 2007). Di Indonesia terdapat 13 jenis ikan patin, namun baru 2 spesies yang telah berhasil dibudidayakan yakni ikan patin siam dan patin jambal. Selain di Indonesia, ikan patin juga banyak ditemukan di kawasan Asia lainnya seperti di Vietnam, Thailand, dan Cina (Ghufran, 2010).

Pakan memberikan kontribusi terbesar yaitu mencapai 60-70 \% dari total biaya produksi. Tingginya biaya produksi akibat mahalnya harga pakan dan kebutuhan pakan yang tinggi mendorong perkembangan metode pemberian pakan yang efisien dan dan efektif (Rahim, 2018; Rahim, 2018; Rahim et al., 2016; Rahim, et al., 2015). Pemberian pakan yang efisien dan efektif mampu menekan biaya produksi dan mengurangi dampak negatif pakan terhadap lingkungan. Usaha efisiensi pakan yang telah dilakukan adalah dengan penyusunan kandungan gizi pada pakan ikan, dan mensubtitusi atau menganti sumber protein lain yang lebih mudah didapat dan murah kedalam pakan. Metode lain yang lebih sederhana dan mudah diterapkan oleh pembudidaya untuk mengefisienkan kebutuhan pakan adalah metode pemuasaan secara periodik atau Starving.

Pemuasaan merupakan salah satu cara yang dapat digunakan untuk mengurangi konsumsi pakan maupun akumulasi amonia (Tahe, 2008). Pemuasaan secara periodik mampu meningkatkan kecepatan pertumbuhan ikan setara bahkan lebih tinggi jika dibandingkan dengan tanpa pemuasaan (Rachmawati et al., 2010). Hal tersebut disebabkan pertumbuhan kompensatori (compensatory growth) yaitu pertumbuhan yang lebih cepat dibandingkan dengan pemberian pakan normal yang terjadi setelah ikan melewati periode pembatasan pemberian pakan lalu diberi pakan kembali sesuai dengan kebutuhan. Pemuasaan secara periodik mampu meningkatkan kecepatan pertumbuhan ikan bahkan lebih tinggi dibandingkan tanpa memuasaan.

\section{STUDI LITERATUR}

Ikan patin (Pangasius $s p$ ) adalah salah satu ikan asli perairan Indonesia yang telah berhasil didomestikasi. Jenis-jenis ikan patin di Indonesia sangat banyak, antara lain Pangasius pangasius atau Pangasius jambal, Pangasius humeralis, Pangasiuslithostoma, Pangasius nasutus, pangasius polyuranodon, Pangasius niewenhuisii. Sedangkan Pangasius sutchi dan Pangasius hypophtalmus yang dikenal sebagai jambal siam atau lele bangkok merupakan ikan introduksi dari Thailand (Kordi, 2005). 
Ikan patin mempunyai bentuk tubuh memanjang, berwarna putih perak dengan punggung berwarna kebiruan. Ikan patin tidak memiliki sisik, kepala ikan patin relatif kecil dengan mulut terletak diujung kepala agak ke bawah. Hal ini merupakan ciri khas golongan catfish. Ikan patin dalam menjalani hidupnya mengalami perkembangan atau fase yang akan dijalaninya selama beberapa waktu sampai akhirnya dapat dikonsumsi ataupun dijadikan induk untuk menghasilkan benih-benih yang berkualitas. Menurut Lusac dan Southgate (2012), ikan patin memiliki fase kehidupan yaitu telur, larva, benih dan dewasa.

Habitat ikan patin adalah di tepi sungai - sungai besar dan di muara - muara sungai serta danau. Dilihat dari bentuk mulut ikan patin yang letaknya sedikit agak ke bawah, maka ikan patin termasuk ikan yang hidup di dasar perairan. Ikan patin termasuk jenis omnivora (pemakan segala). Ikan ini biasa memakan ikan-ikan kecil, cacing, serangga, biji-bijian, udang kecil dan moluska. Namun pada stadium larva, ikan lebih bersifat karnivora dan memakan Brachionus sp, Crustacea dan Cladocera. Sementara itu ikan yang dalam stadium larva yang baru habis kuning telurnya mempunyai sifat kanibal yang tinggi (Susanto, 2007).

Ikan patin akan lebih cepat tumbuhnya bila dipelihara pada padat penebaran yang rendah dibandingkan dengan padat penebaran yang tinggi (Fadjar, 1986). Benih berbobot rata - rata 100 gram diterbar dengan kepadatan 1 ekor/m2 (Kordi, 2005). Ikan diberi pakan buatan berupa pellet yang mengandung protein $25-35 \%$ sebanyak $3-$ $5 \%$ dari bobot badan/hari. Dalam pemeliharaan ikan patin, selain pakan faktor lingkungan banyak menentukan pertumbuhan dan kelangsungan hidup. Agar pertumbuhan dan kelangsungan hidup optimal, maka diperlukan kondisi lingkungan yang optimal untuk kepentingan proses fisiologis pertumbuhan (Yuliartati, 2011). Beberapa faktor lingkungan yang berpengaruh, antara lain : suhu, $\mathrm{pH}$ dan DO.

\section{METODE PENELITIAN}

Penelitian dilaksanakan selama 35 hari di Indoor Desa Kandangan RT 01/RW 02 Kecamatan Cerme Kabupaten Gresik, Propinsi Jawa Timur. Peralatan yang digunakan dalam penelitian ini adalah jaring atau seser, timbangan digital, penggaris, aerator, selang aerasi, PH meter (digital), DO meter (digital), Thermometer (digital), terst amoniak (prodact test $\mathrm{NH}_{3} / \mathrm{NH}_{4}$ ), wadah bak, pemberat aerasi, dan kamera handphone. Bahan penelitian yang digunakan ikan patin ukuran 9-10 cm yang didatangkan dari Desa Pandanan Kabupaten Gresik, Jawa Timur. Ikan kemudian ditebar di wadah ember .

Metode yang digunakan dalam penelitian ini adalah metode eksperimen dengan menggunakan analisis Rancangan Acak Lengkap (RAL), yang terdiri dari empat perlakuan dengan tiga kali ulangan dan menggunakan 10 ekor ikan pada setiap ulangan perlakuan. Sehingga terdapat 12 unit percobaan. Ikan patin dipuasakan sesuai jam yang telah ditentukan diperlakuan. 
Perlakuan A : (pemuasaan 8 jam)

Perlakuan B : (pemuasaan 12 jam)

Perlakuan $\mathrm{C} \quad$ : (pemuasaan 24 jam)

Perlakuan D : (pemuasaan 48 jam)

Persiapan wadah merupakan tahapan yang meliputi persiapan wadah ember sebanyak 12 ember dibagi menjadi empat perlakuan, tiga kali ulangan. selanjutnya membersihkan wadah ember, mensterilkan wadah ember dengan menjemur di terik matahari, persiapan aerasi meliputi, aerator, selang aerasi, dan batu aerasi. Selama masa pemeliharaan, benih ikan patin diberi pakan sesuai masing-masing perlakuan sebanyak 5\% dari bobot ikan. setiap 1 minggu sekali di ukur berat dan panjang ikan patin.

\section{Bobot mutlak (gram)}

Rumus yang digunakan untuk menghitung pertumbuhan bobot menurut Effendie (2002) adalah :

$$
W=W t-W o
$$

Keterangan :

$\mathrm{W}:$ Pertumbuhan bobot mutlak (g)

Wt : Bobot ikan akhir (g)

Wo : Bobot ikan awal (g)

\section{Pertumbuhan Panjang Mutlak (cm)}

Laju pertumbuhan panjang harian dihitung dengan modifikasi rumus Busacker et al. (1990) :

$$
\mathbf{P h}=\frac{\mathbf{L t}-\mathbf{L o}}{\mathrm{T}} \times \mathbf{1 0 0 \%}
$$

Keterangan :

$\mathrm{Ph}_{\mathrm{h}}$ : Pertumbuhan panjang harian $(\%)$

Lo : Panjang rata-rata awal $(\mathrm{cm})$

$\mathrm{Lt}$ : Panjang rata-rata akhir $(\mathrm{cm})$

$\mathrm{T}$ : Lama pemeliharaan (hari) 


\section{FCR ( Rasio Konfersi Pakan )}

Menurut Effendi (2003), FCR dapat dihitung dengan menggunakan rumus sebagai berikut :

$$
\mathbf{F C R}=\frac{\mathbf{F}}{\mathbf{W t}-\mathbf{W o}_{0}}
$$

Keterangan :

$\begin{array}{ll}\text { FCR } & \text { : Feed Convertion Ratio } \\ \mathrm{F} & \text { : Jumlah pakan yang diberikan selama masa pemeliharaan }(\mathrm{kg}) \\ \mathrm{Wt} & \text { : Biomassa akhir (gram) } \\ \text { Wo } & \text { : Biomassa awal ( gram ) }\end{array}$

Data yang telah diperoleh kemudian ditabulasi dan dianalisis menggunakan program SPSS 16, Analisis Ragam (ANOVA) dengan uji F pada selang kepercayaan $95 \%$, digunakan untuk menentukan apakah perlakuan berupa pertumbuhan dan FCR memberikan pengaruh yang nyata $(\mathrm{P}<0,05)$ maka akan dilakukan uji lanjut tukey.

\section{HASIL DAN PEMBAHASAN}

\section{Bobot Mutlak (gr)}

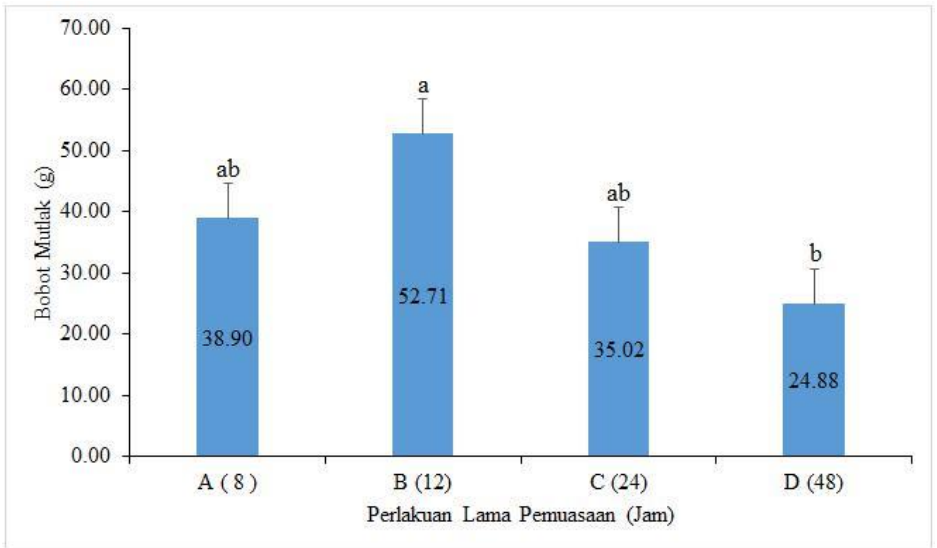

Gambar 1. Grafik Bobot Mutlak (g) Ikan Patin

Lebih tingginya pertumbuhan pada $\mathrm{B}$ diduga berkaitan dengan respon hiperfagia selama periode pemberian pakan kembali. Hiperfagia merupakan kondisi nafsu makan meningkat setelah ikan mengalami pemuasaan, sehingga meningkatkan konsumsi pakan ketika pemberian pakan kembali (Chatakondi dan Yant, 2001). Peningkatan konsumsi pakan selama hiperfagia tersebut dapat memberikan pasokan nutrisi yang cukup untuk memenuhi kebutuhan metabolisme setelah ikan dipuasakan sehingga dapat meningkatkan pertumbuhan (Yuwono et al., 2005). Relatif kecilnya perbedaan pertumbuhan antara ikan yang dipuasakan dengan ikan yang tidak dipuasakan diduga karena pemuasaan secara periodik mempengaruhi pemanfaatan 
energi selama ikan tidak memperoleh asupan pakan (Tahe, 2008). Walaupun, ikan dipuasakan namun ikan tersebut mampu mengalami catch-up growth sehingga ikanikan yang mengalami pemuasaan dapat mencapai berat tubuh sama bahkan lebih tinggi jika dibandingkan dengan ikan yang tidak dipuasakan (Anin et al., 2007).

\section{Panjang Mutlak (cm)}

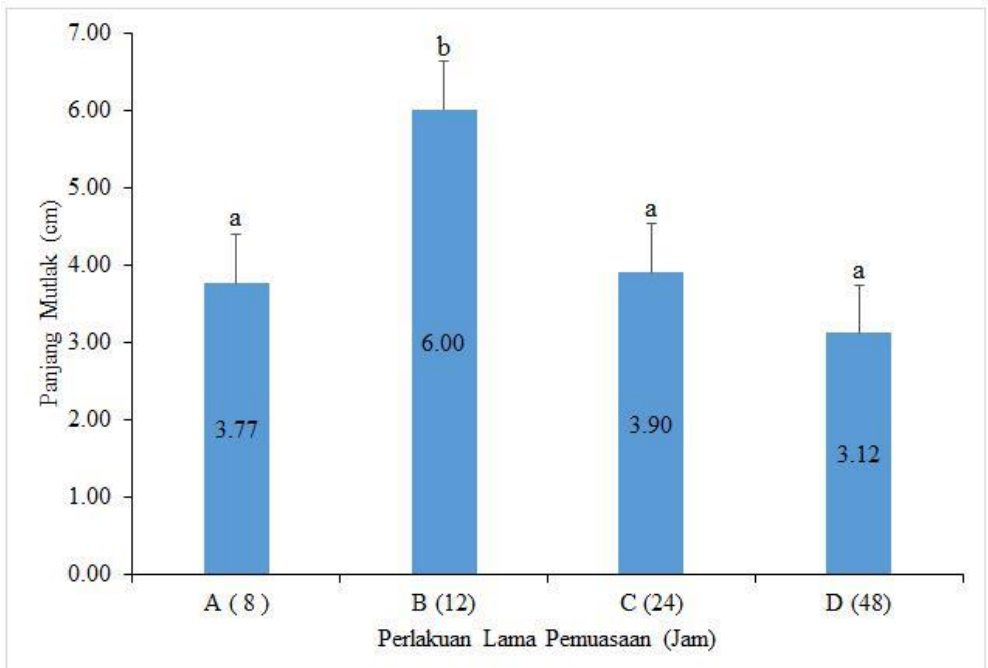

Gambar 6. Panjang Mutlak (cm)

bahwa perlakuan B (lama pemuasaan 12 jam) memberikan pertumbuhan panjang mutlak paling tinggi yaitu sebesar $6,00 \mathrm{~cm}$ dan pertumbuhan panjang mutlak terendah pada perlakuan D (lama pemuasaan 48 jam) yaitu sebesar 3,12 cm. Lebih tingginya pertumbuhan panjang mutlak pada perlakuan B dibanding perlakuan D disebabkan ikan uji pada perlakuan B lebih banyak mengkonsumsi pakan, dimana pakan merupakan sumber nutrisi untuk pertumbuhan. Perlakuan B memberikan hasil laju pertumbuhan relatif pada ikan uji yang lebih tinggi hal tersebut karena adanya ketersediaan energi yang berasal dari pakan untuk pertumbuhan. Prinsip pemuasaan (starving) adalah ikan yang dipelihara pada periode yang cukup atau satiation level, akan terjadi pertumbuhan yang cepat setelah periode starving. Menurut Ekasanti (2007) lebih tingginya pertumbuhan pada ikan yang dipuasakan diduga berkaitan dengan respon hiperfagia selama periode pemberian pakan kembali.

\section{Rasio Konversi Pakan (FCR)}

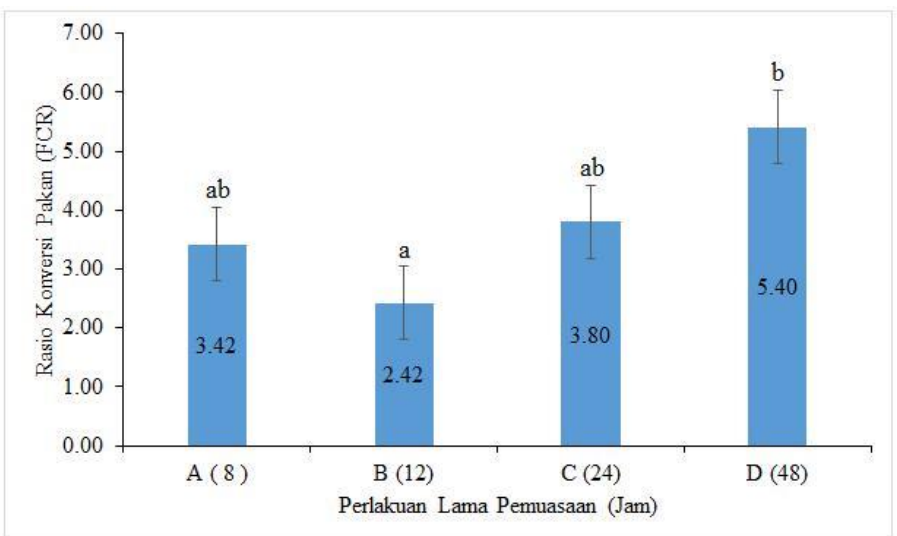

Gambar 7. Rasio Konversi Pakan (FCR) 
Perlakuan dengan dipuasakan mempunyai nilai FCR yang terbaik yaitu pada perlakuan satu hari tidak diberi pakan, Hal ini diperkirakan terjadi karena pada ikan yang mendapatkan pakan setiap hari akan mengalami penurunan nafsu makan dibanding dengan ikan patin yang dipuasakan. Keadaan tersebut menyebabkan pertumbuhan ikan yang diberi pakan setiap hari tidak mendapatkan pertumbuhan yang lebih baik dibanding ikan patin yang dipuasakan (Sealey et al., 1998).

\section{KESIMPULAN DAN SARAN}

1. Pemuasaan ikan patin (pangasius $s p$ ) berpengaruh nyata terhadap Bobot Mutlak, Panjang Mutlak, dan FCR. perlakuan B merupakan perlakuan terbaik dengan pemuasaan ikan selama 12 jam.pada parameter laju pertumbuhan spesifik harian (\%/hari) perlakuan terbaik yaitu perlakuan A.

2. Pada penelitian ini FCR ikan patin (pangasius $s p$ ) menunjukkan bahwa perlakuan B (lama pemuasaan 12 jam) memberikan perbedaan nilai rasio konfersi pakan (FCR) yang nyata terhadap perlakuan D (lama pemuasaan 48 jam) sedangkan perlakuab $\mathrm{C}$ dan $\mathrm{A}$ tidak memberikan perbedaaan nilai rasio konfersi pakan (FCR) yang nyata.

Sebaiknya pemuasaan pada ikan patin untuk dijadikan strategi budidaya dalam pemberian pakan karena menghasilkan nilai yang baik pada bobot mutlak, panjang mutlak dan FCR.

\section{UCAPAN TERIMA KASIH}

Terima kasih disampaikan kepada segenap pihak yang telah membantu dalam pelaksanaan penelitian ini terutama kepada Dosen pembimbing Dr. Andi Rahmad Rahim, S.Pi,.M.Si dan Muh. Sulaiman Dadiono, S.Pi,.MP serta seluruh Dosen Program Studi Akuakultur. Teman-teman Program Studi Akuakultur terutama angkatan 2015 yang telah banyak membantu baik material maupun spiritual.

\section{DAFTAR PUSTAKA}

Anin, E. P. Sukardi., E. Yuwono. 2007. Pertumbuhan Ikan Bawal Air Tawar (Colossoma macropomum). Jurnal Aquaculture Indonesiana. 8 (3) : 183-188.

Busacker GP, Adelman IR, \& Goolish EM. 1990. Growth. p. 363-382 in Schreck CB \& Moyle PB (Editor), Methods for Fish Biology. Maryland USA: American Fisheries Society.

Chatakondi, N.G. and R.D. Yant. 2001. Application of compensatory growth to enhance production in channel catfish Ictalurus punctatus. Journal of the World Aquaculture Society, 32 (3): 278- 285.

Djarijah, A.S. 2001. Budi Daya Ikan Patin. Kanisius. Yogyakarta. 
Ekasanti, P. Sukardi dan E. Yuwono. 2007 .Pertumbuhan Ikan Bawal Air Tawar ( $C$. macropomum) yang di puasakan Secara Periodik. Aquacultura Indonesiana. (3) : 183-188 ISSN 0216-0749.

Effendie, M. I. 2002. Probiotics for marine Organism Disease Protection.Pekanbaru : Fakultas Perikanan dan Ilmu Kelautan Universitas Riau.

Effendi, I. 2003. Metode Biologi Perikanan. Yayasan Dewi Sri Bogor. $112 \mathrm{hlm}$. Fadjar, M., 1986. Pengaruh Pemberian Makanan Buatan dengan Kadar Protein Berbeda Terhadap Konsumsi Harian Maksimum Benih Ikan Lele (Clarias batracus L.). Karya Ilmiah, Fakultas Perikanan IPB, Bogor.

Ghufran, K,K. 2010. Budidaya Ikan Patin di Kolam Terpal. LILY Publisher. Yogyakarta. Hal 7 - 11.

Kordi, K.M.G.H.,2005. Budidaya Ikan Patin Biologi, Pembenihan dan Pembesaran. Yayasan Pustaka Nusatama. Yogyakarta.

Rachmawati, F.N., U. Susilo dan Y. Sistina. 2010. Respon fisiologi ikan nila (Oreochromis niloticus) yang distimulasi dengan daur pemuasaan dan pemberian pakan kembali. Seminar Nasional Biologi, tanggal 24-25 September 2010. Fakultas Biologi Universitas Gajah Mada. Yogyakarta.

Rahim, A. R., Herawati, E. Y., Nursyam, H., Hariati, A. M. 2015. Cells Characteristics, Growth, and Quality of Gracilaria verrucosa Seaweed Production with Different Doses of Vermicompost Fertilizer. International Journal of Science Technology and Engineering, Volume 2, Issue 1.

Rahim, A. R., Herawati, E. Y., Nursyam, H., Hariati, A. M. 2016. Combination of Vermicompost Fertilizer, Carbon, Nitrogen and Phosphorus on Cell Characteristics, Growth and Quality of Agar Seaweed Gracilaria verrucosa. Nature Environment \& Pollution Technology, 15(4).

Rahim, A. R. 2018. Application of Seaweed Gracilaria verrucosa Tissue Culture using Different Doses of Vermicompost Fertilizer. Nature Environment and Pollution Technology, 17(2), 661-665.

Rahim, A. R. 2018. Utilization of Organic Wastes for Vermicomposting Using Lumbricus rubellus in Increasing Quality and Quantity of Seaweed Gracilaria verrucosa. Asian Journal of Microbiology, Biotechnology and Environmental Sciences. Volume 20, No. 2: 2018: S17 - S23.

Sealey WM., Davis JT., dan Gatlin DM. 1998. Restricted feeding regimes increase production efficiency in channel catfish. Journal of Southern Regional Aquaculture Center Publication. 18(92): 13-32.

Susanto, H dan Khairul A. 2007. Budidaya Ikan Patin. Penebar Swadaya. Jakarta. Lusac JS, Southgate PC. 2012. Aquaculture. UK : Willey Publishing Science. Tahe, S. 2008. Pengaruh starvasi ransum pakan terhadap pertumbuhan, sintasan dan produksi udang vanamei (Litopenaeus vannamei) dalam wadah terkontrol. Jurnal Riset Akuakultur. 3 (3) : 401-412.

Yuwono, E., P. Sukardi dan I. Sulistyo. 2005. Konsumsi dan efisiensi pakan pada ikan kerapu bebek (Cromileptes altivelis) yang dipuasakan secara periodik. Berk. Penel. Hayati. 10 : 129-132. 
Yuliartati, E. 2011. Tingkat Serangan Ektoparasit pada Ikan Patin (Pangasius Djambal) pada Beberapa Pembudidaya Ikan di Kota Makassar. Skripsi. Jurusan Perikanan, Fakultas Ilmu Kelautan dan Perikanan, Universitas Hasanuddin Makassar. 